\title{
Pengaruh Penambahan Nitrogen pada Pupuk Cair dan Musim Terhadap Kandungan Bahan Aktif Epigalokatekin Galat (EGCG) Pucuk Teh (Camellia sinensis L.)
}

\author{
Zakarias Frans Mores Hukom
}

\author{
Program Studi Agroteknologi, Jurusan Budidaya Pertanian, Fakultas Pertanian Universitas Pattimura \\ Jl. Ir. M. Putuhena, Kampus Poka, Ambon 97233 \\ Email: zakariahukom@gmail.com
}

\begin{abstract}
ABSTRAK
Epigalokatekin Galat (EGCG) adalah senyawa bioaktif turunan katekin pucuk teh yang memiliki sifat antioksidan sangat tinggi. EGCG banyak digunakan sebagai bahan baku terapi penyembuhan berbagai penyakit degenerative. Kandungan EGCG pada pucuk teh sangat ditentukan oleh faktor iklim dan manajemen teknik budidaya terutama pasokan hara nitrogen sebagai elemen kunci pada tahap awal biosintesis prekusor katekin. Penelitian ini bertujuan untuk menentukan pengaruh penambahan tingkat $\mathrm{N}$ pada pupuk cair terhadap kandungan bahan aktif EGCG pucuk teh pada musim hujan dan kemarau. Rancangan percobaan yang digunakan yaitu acak kelompok lengkap yang terdiri dari 5 tingkat pemupukan di musim hujan dan kemarau. Hasil penelitian menunjukkan bahwa aplikasi pupuk cair tanpa penambahan $\mathrm{N}$ di musim kemarau memberikan pengaruh signifikan terhadap kandungan EGCG pucuk dan lebih tinggi $12,53 \%$. Kandungan EGCG lebih tinggi 97,45\% sampai 98,16\% dari kandungan EGCG pada musim hujan dan $63,73 \%$ lebih tinggi dari tanaman kontrol pada musim kemarau.
\end{abstract}

Kata Kunci: EGCG, Musim,Penambahan N, Pucuk Teh, Pupuk cair.

\section{The Effect of Nitrogen Addition in Liquid Fertilizers and Seasons on the Active Content of Epigallocatech in Gallate (EGCG) Tea Shoots (Camellia sinensis L.)}

\begin{abstract}
Epigallocatechin Gallate (EGCG) is a bioactive compound derived from tea shoot catechin that posing very high antioxidant. EGCG is widely used as raw materials in therapeutic healing of various degenerative diseases. EGCG content in tea shoots is largely determined by climatic factors and cultivation technique management, especially nitrogen nutrient supply as a key element in the early stages of catechin precursor biosynthesis. This study aims to determine the effect of adding $\mathrm{N}$ levels in liquid and seasonal fertilizers on the active content of EGCG tea shoots. The experimental design used was a complete randomized consisting of 5 levels of fertilization in rainy and dry seasons. The results showed that the application of liquid fertilizer without the addition of $\mathrm{N}$ in the dry season has a significant effect on the EGCG content of tea shoots and 12,35\% higher than the rainy season. The EGCG content in the dry season is $97.45 \%$ to $98.16 \%$ higher than the rainy season, and $63.73 \%$ is higher than the control plants in the dry season.
\end{abstract}

Keywords: EGCG, Season, N addition, Tea shoot, Liquid fertilizer.

\section{PENDAHULUAN}

Teh (Camellia sinensis (L) O. Kuntze) adalah tanaman terpopuler di dunia sebagai penghasil bahan baku pembuat minuman, industri pengolahan pangan funsional dan industri farmasi. Kandungan bahan aktif pucuk teh sangat bermanfaat untuk pemulihan kesehatan badan dan tidak memberikan dampak negatif ${ }^{[1]}$.

Pucuk Teh Indonesia dikenal karena memiliki kandungan katekin (antioksidan 
alami) tertinggi di dunia ${ }^{[2]}$. Katekin adalah salah satu jenis senyawa fitokimia turunan dari poliphenol yang memiliki khasiat antioksidan yang tinggi. Faktor yang mempengaruhi kadar katekin adalah jenis kultivar, ketinggian tempat, Iklim, tingkat kesuburan tanah, umur daun dan jenis pucuk. Dipandang dari sisi kesehatan, makin tinggi kandungan katekin dalam bahan baku pucuk teh berarti makin bermanfaat bagi kesehatan. Kandungan katekin pucuk teh berkisar antara $10-30 \%$ dari seluruh berat kering daun ${ }^{[3,4]}$.

Senyawa turunan katekin yang ditemukan dalam pucuk teh merupakan senyawa kompleks yang terdiri dari epikatekin (EC), epikatekin galat (ECG), epigalokatekin (EGC), epigalokatekin galat (EGCG) dan galokatekin (GC) (Gambar 1). Komponen yang mendominasi dan mempunyai sifat akivitas biologis sebagai antioksidan yang paling tinggi adalah ECGC ${ }^{[2]}$. Kandungan ECGC dan ECG yang tinggi dalam pucuk teh menyebabkan pucuk teh dijadikan komoditi pertanian komersial penting ${ }^{[5]}$. Beberapa hasil penelitian terdahulu telah melaporkan bahwa EGCG sebagai indikator utama yang menentukan kualitas pucuk teh. Produksi dan akumulasi metabolit tersebut dalam pucuk tanaman teh merupakan komponen kualitas teh yang paling penting manfaatnya ${ }^{[3]}$. Hasil penelitian di perkebunan teh plasma menunjukkan bahwa klon TRI 2025 memiliki kandungan EGCG yang lebih tinggi dari enam klon unggul yang diuji pada ketinggian 889 1346 meter dari permukaan laut pada musim hujan dan kemarau ${ }^{[6,7]}$.

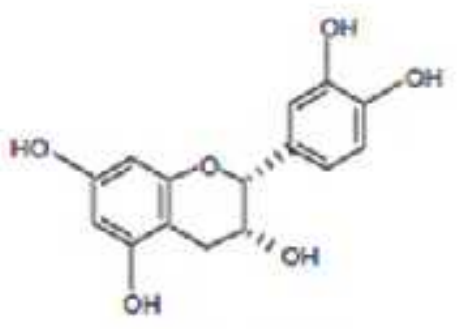

(-)-Epicatechin

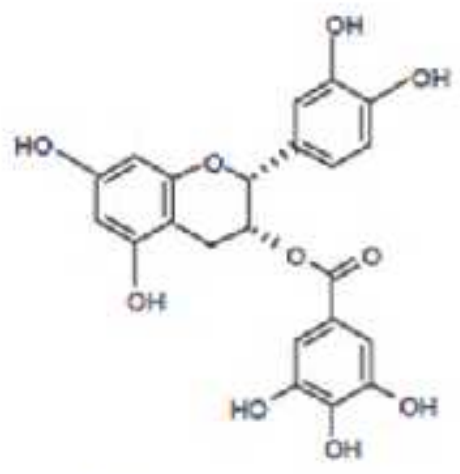

(-)-Epicatechin gallate<smiles>Oc1cc(O)c2c(c1)O[C@H](c1cc(O)c(O)c(O)c1)[C@H](O)C2</smiles>

(-)-Epigallocatechin<smiles>O=C(O[C@H]1Cc2c(O)cc(O)cc2O[C@H]1c1cc(O)c(O)c(O)c1)c1cc(O)c(O)c(O)c1</smiles>

(-)-Epigallocatechin gallate

Gambar 1. Struktur Derivat Senyawa Katekin dalam pucuk teh ${ }^{[3]}$.

Untuk mendapatkan pucuk teh dengan kandungan EGCG yang maksimal diperlukan teknik pemupukan seimbang pada tingkat inisiasi dan regenerasi mata tunas setelah pemetikan pucuk ${ }^{[8]}$. Nitrogen adalah salah satu hara makro primer yang berpengaruh terhadap peningkatan hasil dan kualitas pucuk. Hal ini karena nitrogen merupakan bahan 
dasar pembentuk senyawa asam amino yang berfungsi sebagai prekursor utama pada tahap awal biosintesis katekin ${ }^{[3,9,10,11,12]}$. Aplikasi konsentrasi pupuk nitrogen cair sebesar 3.000 ppm per $\mathrm{m}^{-2}$ melalui metode irigasi automatic drip vertigation system di bawah perdu teh di perkebunan teh Tencha Jepang meningkatkan hasil dan kandungan asam amino jaringan daun masing-masing sebesar $160,00 \%$ dan $17,33 \%$ terhadap pemupukan $\mathrm{N}$ konvensional [10]. Aplikasi konsentrasi nitrogen 1,50 mmol $\mathrm{L}^{-1}$ dalam nutrisi lengkap hidroponik menghasilkan kandungan ECGC pucuk teh yang tertinggi $\left(83,54 \mathrm{mg} \mathrm{g}^{1}\right.$ berat kering) ${ }^{[3]}$.

Dampak pergeseran iklim saat ini telah berpengaruh terhadap penurunan produksi dan kualitas pucuk teh sebesar 20-30 \% dari kondisi normal ${ }^{[13]}$. Penelitian terdahulu melaporkan bahwa akumulasi kadar metabolit sekunder pucuk teh sangat dipengaruhi oleh faktor iklim [14,15]. Musim hujan dengan intensitas curah hujan yang tinggi berpengaruh terhadap penurunan kandungan senyawa metabolit sekunder katekin dan metylxantin pucuk teh mencapai $50 \%$ dibandingkan dengan musim kemarau ${ }^{[16]}$.

Proporsi akumulasi senyawa katekin terutama EGCG dalam pucuk teh merupakan salah satu indikator penentu kualitas pucuk teh premium. Penerapan teknik budidaya teh terutama aplikasi pupuk dan pemberian air irigasi dengan metode yang tepat dan berkelanjutan merupakan kunci pengelolaan teh dalam upaya penyediaan bahan baku industri dengan kandungan senyawa bahan aktif EGCG yang tinggi. Hipotesis yang dikemukakan pada penelitian ini adalah aplikasi pupuk cair tanpa penambahan $\mathrm{N}$ di musim kemarau berpengaruh signifikan dan lebih tinggi terhadap kandungan EGCG pucuk teh.

\section{BAHAN DAN METODE}

Bahan yang digunakan adalah pucuk teh segar klon TRI 2025 sesuai perlakuan di perkebunan teh rakyat Samigaluh, Kulon
Progo, DIY dari bulan Januari 2017 samapi Januari 2018. Penelitian menggunakan rancangan percobaan antar musim $5 \times 2 \times 3$ acak kelompok lengkap yang terdiri dari faktor penambahan Nitrogen pada pupuk cair dan musim. Perlakuan pemupukan terdiri dari 5 tingkat yaitu kontrol atau tanpa pemberian pupuk cair dan tanpa penambahan konsentrasi $\mathrm{N}$ dalam pupuk cair tetapi menggunakan rekomendasi pemupukan konvensional sebanyak $60 \mathrm{~g}$ urea, $10 \mathrm{~g} \mathrm{SP-36}$, dan $20 \mathrm{~g} \mathrm{KCl}$ perdu ${ }^{1}$ tahun ${ }^{1}$, pemberian pupuk cair tanpa penambahan $\mathrm{N}(0 \mathrm{~g} \mathrm{~N}$ dalam pupuk cair); penambahan 2,33 g N; 7,00 g N dan 11,67 g N masing-masing pada pupuk cair. Formula pupuk cair terdiri dari campuran pupuk organik cair dan larutan mineral hidroponik berkadar hara rendah yang dibuat berdasarkan perhitungan formula Resh ${ }^{[17]}$. Komposisi hara pupuk organik cair terdiri dari : 21,6 ppm N; 1,31 ppm P; 7,47 ppm K; 0,12 ppm Ca; 0,3 ppm $\mathrm{Mg} ; 0,3$ ppm Fe; 0,3 ppm Cu; 0,3 ppm $\mathrm{Mn} ; 0,3 \mathrm{ppm} \mathrm{Zn}$ dan 1,6 \% asam amino. Komposisi larutan mineral hidroponik terdiri dari : 27 ppm $\mathrm{KH}_{2} \mathrm{PO}_{4} ; 38,81$ ppm $\mathrm{KNO}_{3} ; 100$ ppm $\mathrm{Ca}\left(\mathrm{NO}_{3}\right)_{2} ; 49,97$ ppm $\mathrm{MgSO}_{4} .7 \mathrm{H}_{2} \mathrm{O}$; 66,66 ppm S; 2 ppm Fe EDTA; 0,5 ppm $\mathrm{MnSO}_{4} \cdot \mathrm{H}_{2} \mathrm{O} ; 0,05$ ppm $\mathrm{CuSO}_{4} ; 0,1 \mathrm{ppm}$ $\mathrm{ZnSO}_{4} ; 0,5$ ppm $\mathrm{H}_{3} \mathrm{BO}_{3}$ dan $0,02 \mathrm{ppm}$ $\mathrm{NaMoO}$. Aplikasi penambahan $\mathrm{N}$ dalam pupuk cair dilakukan dengan interval 10 hari sekali setelah pemetikan pucuk secara kontinu selama satu tahun.

Untuk keperluan analisis kandungan EGCG, pucuk dari setiap perlakuan dipetik pada bulan Maret dasarian kedua untuk mewakili musim hujan dengan jumlah curah hujan dasarian sebesar $125 \mathrm{~mm}$ dan curah hujan bulanan sebesar $647 \mathrm{~mm}$ sedangkan untuk musim kemarau pucuk dipetik pada bulan Oktober dasarian pertama dengan jumlah curah hujan dasarian sebesar $46 \mathrm{~mm}$ dan jumlah curah hujan bulanan sebesar 90 $\mathrm{mm}$. Total konsentrasi $\mathrm{N}$ dan volume aplikasi dari setiap perlakuan penambahan $\mathrm{N}$ pada pupuk cair tertera pada Tabel 1 . 
Hukom Z.F.M, 2020. Pengaruh Penambahan Nitrogen ...

Tabel 1. Dosis Pupuk N-Urea dalam Pupuk Cair dan Volume Larutan Aplikasi dari Setiap Perlakuan.

\begin{tabular}{|c|c|c|c|c|c|c|}
\hline $\begin{array}{c}\text { Penambahan } \mathrm{N} \\
\text { pada } 15 \mathrm{~L} \text { pupuk } \\
\text { cair } 3000 \text { ppm }\end{array}$ & $\begin{array}{c}\text { Total } \\
{[\mathrm{N}]} \\
\text { dalam } \\
\text { pupuk } \\
\text { cair } \\
\text { (ppm)* }\end{array}$ & $\begin{array}{c}\text { Dosis } \\
\text { N-urea } \\
\text { dalam } \\
3000 \\
\text { ppm LS }\end{array}$ & $\begin{array}{l}\text { Jumlah } \\
\text { urea dan } \\
\text { volume } \\
\text { LA } \\
\text { tanaman }^{-1}\end{array}$ & $\begin{array}{c}\text { Total } \\
\text { urea dan } \\
\text { volume } \\
\text { LS } \\
\text { tahun }^{-1}\end{array}$ & $\begin{array}{c}\text { Dosis } \\
\text { N-urea } \\
\text { pada } \\
\text { tanaman } \\
\text { sampel } \\
\text { tahun }^{-1}\end{array}$ & $\begin{array}{l}\text { Dosis N-urea } \\
\text { ha }^{-1} \text { tahun }^{-1}\end{array}$ \\
\hline Kontrol & - & - & $60 \mathrm{~g}$ & $2,88 \mathrm{~kg}$ & $1.325 \mathrm{~g}$ & $383,3 \mathrm{~kg}$ \\
\hline $0 \mathrm{~g} \mathrm{~N}$ & $105,00^{+}$ & $1,24 \mathrm{~g}$ & $0,35 \mathrm{~L}$ & 1,8 Liter & $61,60 \mathrm{~g}$ & $17,8 \mathrm{~kg}$ \\
\hline $2,33 \mathrm{~g} \mathrm{~N}$ & $260,00^{+}$ & $3,57 \mathrm{~g}$ & $0,35 \mathrm{~L}$ & 1,8 Liter & $177,36 \mathrm{~g}$ & $51,32 \mathrm{~kg}$ \\
\hline $7,00 \mathrm{~g} \mathrm{~N}$ & $571,33^{++}$ & $8,24 \mathrm{~g}$ & $0,35 \mathrm{~L}$ & 1,8 Liter & $409,36 \mathrm{~g}$ & $118,44 \mathrm{~kg}$ \\
\hline $11,67 \mathrm{~g} \mathrm{~N}$ & $882,67^{++}$ & $12,91 \mathrm{~g}$ & $0,35 \mathrm{~L}$ & 1,8 Liter & $641,37 \mathrm{~g}$ & $185,57 \mathrm{~kg}$ \\
\hline
\end{tabular}

Keterangan : $\mathrm{LA}=$ larutan aplikasi dalam 15 liter air, $\mathrm{LS}=$ larutan stok pupuk cair, luas area sampel $=$

7,5 $\mathrm{m}^{2}$, jarak tanam $0,6 \times 1,2 \mathrm{~m}$ dan diulang $3 \mathrm{kali}, *=$ kriteria kisaran konsentrasi nutrisi untuk tanaman hidroponik $[18,19,20],{ }^{+}=$cukup, ${ }^{++}=$di atas rata-rata.

\section{Penetapan Kadar EGCG}

Analisis EGCG dilakukan menggunakan metode kromatografi Lapis tipis (KLT). Pengukuran dilakukan pada daun pucuk teh premuim $(p+1, p+2, p+3, b+1, b+2, b+3)$ dari setiap perlakuan dan diambil secara acak pada bidang petik. Tahapan penetapan kadar EGCG sebagai berikut : $50 \mathrm{mg}$ sampel dari setiap perlakuan dilarutkan dengan $5 \mathrm{ml}$ etanol dan divortex selama 2 menit, sonifikasi selama 30 menit dan maserasi selama 24 jam. Filtrat dievaporasikan kemudian diencerkan dengan 1 ml etahanol, spoting sampel pada plate silikagel $\mathrm{F}_{254}$ sebanyak $10 \mu \mathrm{l}$, persiapan pembanding menggunakan standar epigalocatechine gallate (E. Mrk), bahan uji dimasukan ke dalam chamber jenuh fase gerak dengan rasio Chloroform-Asam Asetat-Asam Formiat-Iso Propanol (16-2-2-8), eluasi dan densito spot EGCG pada panjang gelombang $280 \mathrm{~nm}$ dengan winCATS Chromatography manager CAMAG. Kadar EGCG dihitung berdasarkan kurva regresi standar dengan menggunakan rumus :

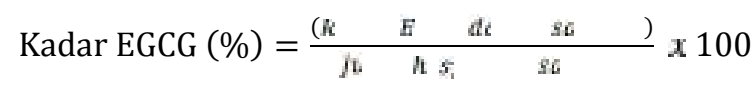

Data hasil analisis kadar bahan aktif EGCG dari setiap perlakuan konsentrasi $\mathrm{N}$ dalam pupuk cair pada musim hujan dan musim kemarau diuji dengan analisis varians (ANOVA) dengan program analisis statistik SAS University. Apabila pada sidik ragam menunjukan pengaruh nyata dari perlakuan, maka dilanjutkan dengan uji Beda Nyata Tukey (BNT) pada taraf $5 \%$. Pola respon variabel pengamatan kandungan bahan aktif EGCG pucuk teh dari setiap perlakuan ditentukan dengan analisis regresi pada tingkat $5 \%$ dengan menggunakan program exel for Windows 2010.

\section{HASIL DAN PEMBAHASAN}

Bahan aktif adalah senyawa bioaktif alamiah turunan polyphenol yang dihasilkan tanaman teh untuk melindungi dan mempertahankan kehidupannya terhadap berbagai faktor eksternal yang merugikan. Oleh karena itu kandungan EGCG dalam pucuk teh merupakan komponen penentu kualitas pucuk teh sebagai bahan baku industri minuman, pangan funsional, farmasi, pupuk organik, pestisida dan herbisida nabati [21]. Data kadar EGCG pada pucuk teh setelah penambahan berbagai tingkat $\mathrm{N}$ dalam pupuk cair pada musim hujan dan kemarau disajikan pada Tabael 2. 
Tabel 2. Kadar EGCG Pucuk Teh pada Penambahan Berbagai Tingkat N dalam Pupuk Cair pada Musim Hujan dan Kemarau (\% mg/g Berat kering).

\begin{tabular}{|c|c|c|c|c|}
\hline \multirow[b]{2}{*}{$\begin{array}{l}\text { Penambahan } \mathrm{N} \text { dalam } \\
3000 \text { ppm pupuk cair }(\mathrm{g})\end{array}$} & \multicolumn{2}{|c|}{ Musim Hujan } & \multicolumn{2}{|c|}{ Musim Kemarau } \\
\hline & $\begin{array}{c}\text { Kandungan } \\
\text { EGCG } \\
(\% \mathrm{~b} / \mathrm{b})\end{array}$ & $\begin{array}{l}\text { Perbedaan terhadap } \\
\text { penambahan pupuk } \\
\text { cair di musim } \\
\text { kemarau }(\%)\end{array}$ & $\begin{array}{l}\text { Kandungan } \\
\text { EGCG } \\
(\% \text { b/b })\end{array}$ & $\begin{array}{c}\text { Perbedaan } \\
\text { terhadap } \\
\text { penambahan } \\
\text { pupuk cair }(\%)\end{array}$ \\
\hline Kontrol & $0,23 \mathrm{~d}$ & 98,16 & $1,06 \mathrm{~d}$ & 91,54 \\
\hline 0 (hanya pupuk cair) & $0,32 \mathrm{~d}$ & 97,45 & $12,53 \mathrm{a}$ & - \\
\hline 2,33 & $0,29 \mathrm{~d}$ & 97,69 & $11,87 \mathrm{ab}$ & 51,35 \\
\hline 7,00 & $0,27 \mathrm{~d}$ & 97,85 & $11,06 \mathrm{ab}$ & 53,12 \\
\hline 11,67 & $0,25 \mathrm{~d}$ & 98,00 & $9,70 \mathrm{c}$ & 55,15 \\
\hline Rerata & 0,27 & & 9,24 & + \\
\hline
\end{tabular}

Keterangan : $B N T$ interaksi $\alpha(0,05)=1,09$.

$+=$ interaksi. Angka yang diikuti dengan huruf yang sama menunjukkan perbedaan yang tidak signifikan sedangkan angka yang diikuti dengan huruf yang berbeda menunjukan adanya perbedaan yang signifikan ${ }^{[22]}$.

Pada Tabel 2 dapat diketahui bahwa Kadar EGCG pucuk teh musim hujan tidak dipengaruhi oleh pemberian pupuk cair dan atau tanpa penambahan $\mathrm{N}$ tetapi terpangaruh pada musim kemarau. Pemberian pupuk cair tanpa penambahan $\mathrm{N}$ memberikan pengaruh tertinggi terhadap peningkatan kadar EGCG pucuk teh. Kadar EGCG pucuk teh akibat pemberian pupuk cair tanpa penambahan $\mathrm{N}$ tersebut memberikan pengaruh lebih tinggi secara berturut-turut $91,54 \%$ dan $98,16 \%$ dari tanaman kontrol pada musim kemarau dan musim hujan atau 97,45\% lebih tinggi dari kadar EGCG tanaman yang diberi pupuk cair tanpa penambahan $\mathrm{N}$ di musim hujan. Hal ini disebabkan karena kandungan hara $\mathrm{N}$ dalam pupuk cair berada pada konsentrasi cukup dan seimbang untuk kebutuhan tanaman $(105,00$ ppm) (Tabel 1). Apablia pada pupuk cair ditambahkan 2,33 g N maka total konsentrasi $\mathrm{N}$ pada larutan aplikasi meningkat menjadi 260,00 ppm (Tabel 1) sehingga konsentrasi N berada pada kisaran konsentrasi rata-rata kebutuhan tanaman ${ }^{[18,19,20]}$. Besarnya total konsentrasi $\mathrm{N}$ pada pupuk cair tanpa penambahan $\mathrm{N}$ atau penambahan $2,33 \mathrm{~g} \mathrm{~N}$ tersebut sangat penting untuk sintesis asam amino dan enzim PAL sebagai prekursor utama dalam jalur biosintesis metabolit sekunder EGCG ${ }^{[3,11]}$ (Gambar 2). Tingginya kadar EGCG di musim kemarau disebabkan karena lebih banyak cahaya matahari yang diserap oleh phytochrom daun untuk mengsintesis kadar klorofil $\mathrm{b}^{[22]}$. Phytochrom dapat mengontrol perubahan struktur protein klorofil pada cahaya merah dengan panjang gelombang $730 \mathrm{~nm}$ untuk menghasilkan isomerisasi ikatan rangkap yang dapat diperluas sampai batas tertentu pada panjang gelombang 660-700 nm ${ }^{[23]}$. Faktor suhu dan intensitas cahaya matahari tidak berpengaruh langsung terhadap kapasitas biosintesis katekin, tetapi dikendalikan oleh kandungan klorofil daun [24]. Hal ini didukung dengan hasil analisis korelasi yang menunjukkan bahwa terdapatnya hubungan yang kuat antara kadar EGCG pucuk teh dengan sekapan cahaya $\left(\mathrm{r}=0,69^{*}\right)$, kadar klorofil-b $(\mathrm{r}=$ $\left.0,85^{* *}\right)$, kandungan $\mathrm{N}$ total tanah $\left(\mathrm{r}=-0,70^{*}\right)$, dan kandungan $\mathrm{N}$ daun $\left(0,63^{*}\right)^{[22]}$.

Penambahan $\mathrm{N}$ yang tinggi $(11,67 \mathrm{~g} \mathrm{~N})$ pada pupuk cair di musim kemarau berpengaruh terhadap penurunan kadar EGCG pucuk teh (Tabel 2 dan Gambar 3). Kondisi ini 
disebabkan karena kandungan total konsentrasi ion $\mathrm{N}$ dalam formula tersebut berada pada kisaran konsentrasi di atas rata-rata kebutuhan tanaman (882,67 ppm) (Tabel 1). Besarnya konsentrasi tersebut cenderung berpengaruh terhadap penurunan kemampuan penyerapan hara oleh akar sehingga terjadi penurunan sintesis enzim-enzim yang berperan langsung pada jalur biosintesis metabolit sekunder EGCG.

Kadar EGCG pucuk teh musim hujan selalu lebih rendah dari musim kemarau. Hal ini disebabkan karena pada musim hujan jumlah curah hujan tinggi dengan interval waktu yang panjang, mengakibatkan banyak hara $\mathrm{N}$ yang terlindi (leaching) keluar dari area perakaran tanaman melalui aliran air perkolasi dan aliran air permukaan (run off) sehingga terjadi cekaman $\mathrm{N}$ yang berpengaruh terhadap penurunan biosintesis klorofil $\mathrm{b}^{[22]}$. Pengaruh tersebut disebabkan karena kapasitas sintesis ANS (aktivitas anthocyanidin synthase) dan LAR (leucocyanidin reduktase) dalam pucuk teh. ANS adalah 2-oxoglutarate oxygenase$\mathrm{Fe}$ bebas yang menggunakan molekul oksigen sebagai co-substrate [25] sedangkan LAR merupakan suatu enzim karakterisasi yang mempercepat konversi leucocyanidin menjadi (+) - catechin ${ }^{[26]}$. Aktivitas LAR biasanya menurun selama perkembangan jaringan pucuk dan daun muda ${ }^{[27]}$. Penurunan aktivitas LAR akan meningkatkan aktivitas ANS dan bepengaruh terhadap akumulasi klorofil a yang lebih banyak dari klorofil $b^{[22]}$. Proporsi akumulasi klorofil a yang lebih tinggi dari klorofil b dalam pucuk teh berpengaruh terhadap akumulasi epikatekin (EC) dan epigalokatekin (EGC) [24] dibandingkan dengan EGCG. Rendahnya kadar klorofil b daun di musim hujan berpengaruh terhadap penurunan kadar EGCG pucuk teh sehingga memiliki ketahanan yang rendah dan sangat rentan terhadap kerusakan di lapangan akibat stress oksidatif yang disebabkan oleh cekaman abiotik maupun cekaman biotik ${ }^{[22]}$. Cekaman $\mathrm{N}$ berpengaruh langsung terhadap penurunan aktivitas enzim NR ${ }^{[22]}$ yang mengakibatkan penurunan sintesis kadar asam amino $L$ phenilalanin. Asam amino L-phenilalanin adalah prekursor enzim phenilaline ammonialyase (PAL) yang terlibat langsung dalam biosintesis Katekin melalui jalur biosintesis shikimic acid (Gambar 1). Selain itu unsur nitrogen merupakan salah satu komponen penting pembentuk senyawa L-theanine sebagai prekursor biosintesis katekin melalui jalur TCA (Tricarboxylic acid).

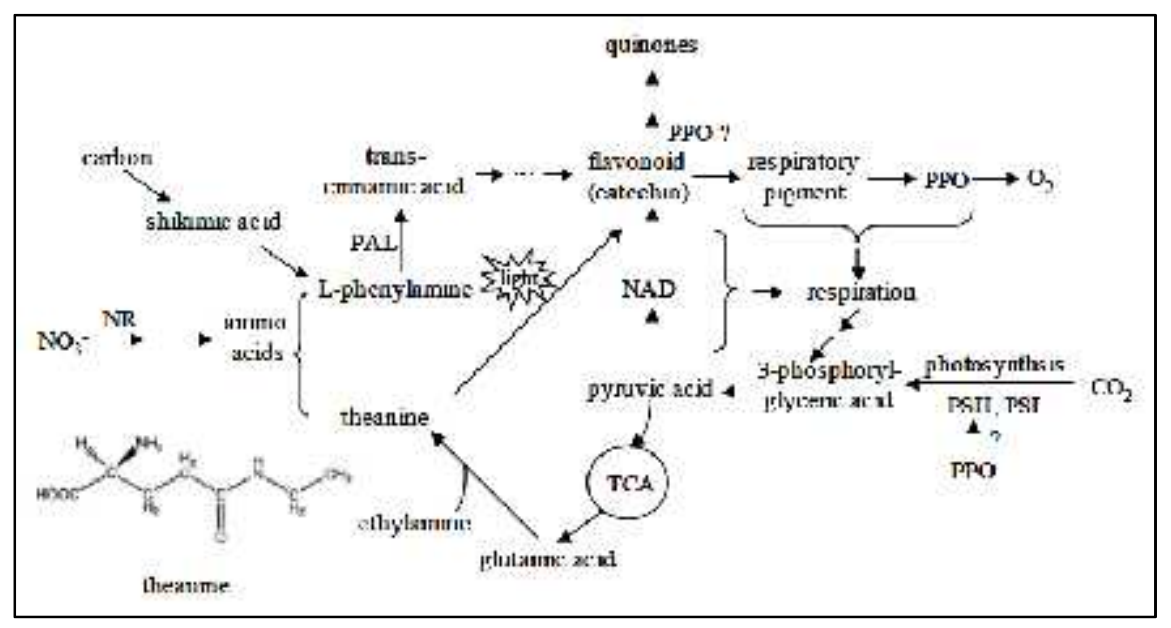

Gambar 2. Pengaruh Nitrogen terhadap sistesis enzim Nitrate Reductase (NR) and Phenylalanine ammonia-lyse (PAL) sebagai enzim kunci pada proses awal biosintesis katekin melalui jalur Shikimic Acid ${ }^{[11]}$ 


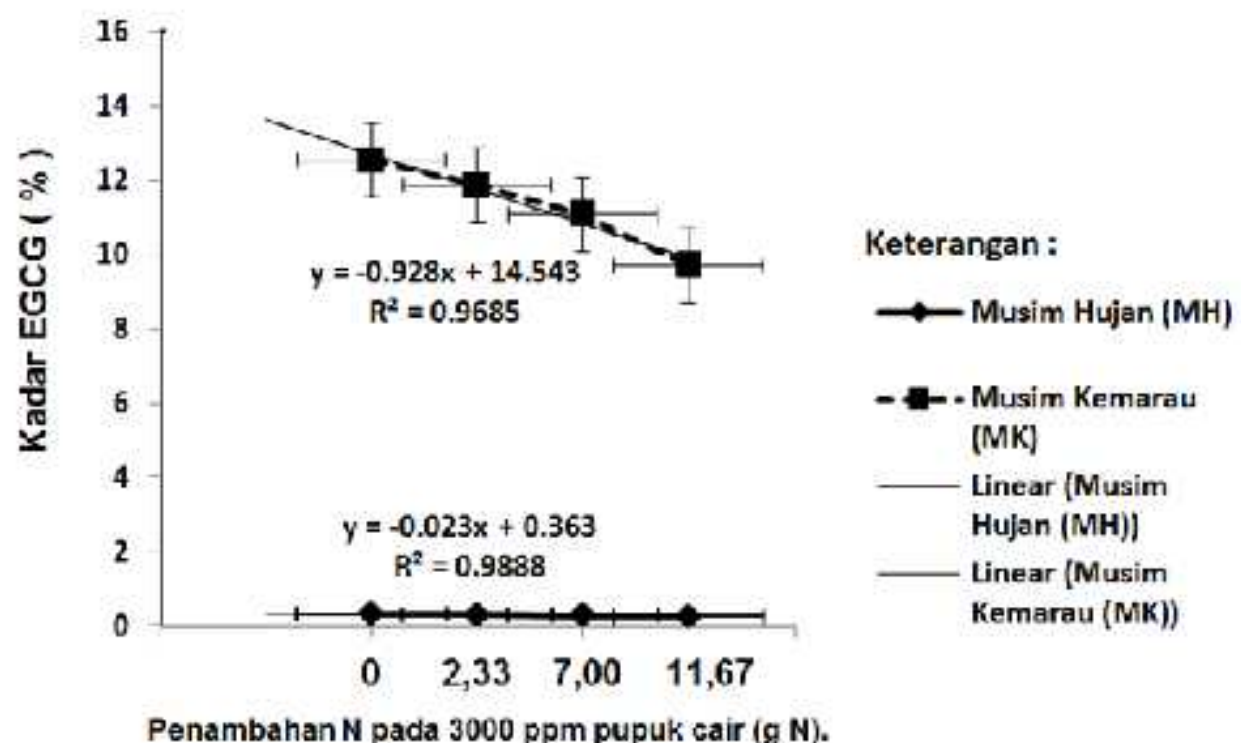

Gambar 3. Grafik kandungan EGCG pucuk teh pada penambahan berbagai tingkat $\mathrm{N}$ pada pupuk cair pada musim hujan dan kemarau.

\section{KESIMPULAN}

Hasil penelitian ini menyimpulkan bahwa pemberian pupuk cair tanpa penambahan $\mathrm{N}$ di musim kemarau berpengaruh terhadap peningkatan kandungan bahan aktif EGCG pucuk teh tertinggi yaitu $12,53 \%(\mathrm{~b} / \mathrm{b})$. Penambahan $\mathrm{N}$ pada pupuk cair cenderung berpotensi terhadap penurunan kandungan EGCG pucuk teh. Semakin tinggi penambahan $\mathrm{N}$ pada pupuk cair $(11,67 \mathrm{~g} \mathrm{~N})$ semakin menurunkan biosentesis EGCG pucuk teh.

\section{DAFTAR PUSTAKA}

[1] Towaha, J. 2013. Kandungan Senyawa Kimia pada Daun Teh (Camellia sinensis). Warta Penelitian dan Pengembangan Tanaman Industri, Balitri. 19 (3): 12-16.

[2] Anjarsari, I.R.D. 2016. Katekin Teh Indonesia : Prospek dan Manfaatnya. Jurnal Kultivasi 15 (2):

[3] Ruan, J. 2005. Quality-Related Constituents in Tea (Camellia sinensis
(L.) O. Kuntze) as Affected by The Form and Concentration of nitrogen. Dissertation zur Erlangung des Doktorgrades der Agrar- und Ernährungswissenschaftlichen Fakultät der Christian-Albrechts-Universität zu Kiel and the supply of chloride. $96 \mathrm{p}$.

[4] Sanyal, S. 2011. Tea Manufacturing Manual. Assam India: Tea Research Association Toklai Experimental Station. Page: 207.

[5] Liu M., H-lu. Tian, J-Hua. Wu, R-Rong. Cang, R-Xian. Wang, X-Hua. Qi, Q. Xu and X-Hao. Chen. 2015. Relationship Between Gene Expression and The Accumulation of Catechin During Spring and Autumn in Tea Plants (Camellia sinensis L.). Citation: Horticulture Research 2, 15011; doi:10.1038/hortres. Nanjing Agricultural University.

[6] Mitrowihardjo, S., W. Mangoendidjoya, H. Hartiko dan P, Yodono. 2009. Hasil Pucuk dan Kadungan Katekin Enam Klon Teh (Camellia sinensis (L.), O. 
Kuntze) di Ketinggian Berbeda. Jurnal Penelitian Teh dan Kina 12 (1-2): 14-20.

[7] Mitrowihardjo, S., Woerjono, M. Hartiko, H dan P. Yudono. 2012. Kandungan Katekin dan Kualitas (Warna Air Seduhan, Flavor, Kenampakan) Enam Klon Teh (Camellia sinensis (L.) O. Kuntze) Di Ketinggian yang Berbeda. Agritech, Vol. 32, No. 2, Mei 2012.

[8] Mokaya, B.N. 2016. Effect of varying rates of organic and inorganic fertilizers on growth, yield and nutrient use efficiency of clonal tea (Camellia sinensis [L.] O. Kuntze). M.Sc. thesis, University of Nairobi, Kenya: 78.

[9] Wang, Y. G., Q.K. Cheng, Y.C. Ruan and W.H. Liu, 1988. Discussion on The Chemical Standards on Quality of Chinese Roasted Green Tea. J. Tea Sci. 8(2): 13-20.

[10] Tsuji M. dan T. Kinoshita 2001. Effect of Liquid Fertilizer Application Under The Canopy of Tencha Tea Garden. Aichi-Ken Agricultural Research Center, Toyohashi Research and Extension Station, 1148 Takayama Imure-cho, Toyohashi-shi, Aich , 4400833, Japan. http://www.ocha festival.jp/archive/english/conference/I COS2001/files/PROC/II-198.pdf.

[11] Li, S. 2005. The Effect of Plant Mineral Nutrition on Yield and Quality of Green Tea (Camellia sinensis L.) Under Field Conditions. Dissertation zur Erlangung des Doktorgrades der Agrar- und Ernährungswissenschaftlichen Fakultät der Christian-Albrechts-Universität zu Kiel. 173 p.

[12] Hamid F.S., Ahmad T, Waheed A, Ahmad N and S. Aslam, 2014. Effect of Different Levels of Nitrogen on the Chemical Composition of Tea $(C$. sinensis L.) grown at higher altitude. J. Mater. Environ. Sci. 5 (1) : 73-80.

[13] Dalimoenthe, S.L. dan Y. Rachmiati. 2010. Pengaruh Pemupukan K dan ZPT pada Tanaman Teh untuk Mengurangi
Resiko Musim Kemarau. Jurnal Penelitian Teh dan Kina 13 (1-2):14-21.

[14] Kumar, R., Singh M and B. Bera. 2015. Influence of Organic, Inorganic and Combined Based Fertilizers on Bush Physiology of Darjeeling tea (Camellia sinensis L.). International Journal of Basic and Applied Biology, Volume 2(4): 265-271.

[15] Yang L., Wen K.S, Ruan X, Zhao Y.X, Wei F, and Q. Wang. 2018. Response of Plant Secondary Metabolites to Environmental Factors. Molecules 23, 762; doi:10.3390/molecules23040762.

[16] Ahmed S, Stepp J.R, Orians C, Griffin T, Matyas C, Robbat A, Cash S, Xue D, Long C, Unachukwu U, Buckley S, Small D, and E. Kennelly. 2014. Effects of Extreme Climate Events on Tea (Camellia sinensis L.) Functional Quality Validate Indigenous Farmer Knowledge and Sensory Preferences in Tropical China. Journal Plos One vol 7(10):e109126.

[17] Resh H.M. 1981. Hydroponic Food Production. Woodbrigde Press

Publishing Company, Santha Barbara, California. $335 \mathrm{p}$.

[18] Douglas J.S. 1985. Edvanced Guide to Hydroponics (soilless cultivation) . Pelham Books LTD. London. p.368.

[19] Sundstrom A.C. 1982. Simple Hidroponics for Australian Home. Gardeners Thomas Nelson Australia. Melbourne. $134 \mathrm{p}$.

[20] Hukom Z.F.M. 2000. Pengaruh Kadar Larutan Landeto dan Gandasil Terhadap Pertumbuhan dan Hasil Buncis Tegak (Phaseolus vulgaris L.) yang Dibudidayakan Secara Hidroponik. Tesis Fakultas Pertanian UGM. Tidak dipublikasikan.

[21] Taulo J.L. 2017. A Multi-Objective Optimization Tool for The Malawian Tea Industry with Sustainability Conciderations. Disseratatiion Presented for The Degree of Doctor of Philosophy in The Faculty of Engineering of 
Stellenbosch University, https://scholar.sun.ac.za. p.202.

[22] Hukom Z.F.M. 2020. Pengaruh Penambahan Nitrogen pada Pupuk Cair dan Musim Terhadap Produktivitas dan kadar Epigallocatechine Gallate (EGCG) Pucuk teh. Disertasi Program Ilmu Pertanian. Program Pascasarjana Fakultas Pertanian Universitas Gadjah Mada. 168 p.

[23] Goodwin, T.G. and E.I. Mercer. 1983. Introduction to Plant Biochemistry Second Edition, Copyright 1983, reprinted 1990. Pergamon Press plc. 645: 4465-479.

[24] Tounekti T, Joubert, E, Hernández I and S. Munné-Bosch. 2012. Inproving the Polyphenol Content of Tea. Critical Reviews in Plant Sciences Publication details, including instructions for authors and subscription information: http://www.tandfonline.com/loi/bpts20. Akses Desember 2018. Towaha, J. 2013.
Kandungan Senyawa Kimia pada Daun Teh (Camellia sinensis). Warta Penelitian dan Pengembangan Tanaman Industri , Balitri. Volume 19 no.3 Desember 2013. p. 12-16.

[25] Cheng L, Xu Y, Grotewold E, Jin Z, Wu F, and C. Fu. 2007. Characterization of anthocyanidin synthase (ANS) gene and anthocyanidin in rare medicinal plant Saussureamedusa. Plant Cell TissueOrgan Cult. 89: 63-73.

[26] Abrahams S, Tanner G.J, Larkin P.J, and A.R. Ashton. 2002. Identification and biochemical characterization ofmutants in the proanthocyanidin pathway in Arabidopsis. Plant Physiol. 130: 561576.

[27] Skadhauge B, Gruber M.Y, Thomsen K.K, and D. Vonwettstein. 1997. Leucocyanidin reductase activity and accumulation of proanthocyanidins in developin legume tissues. Am. J. Bot. 84: 494-503. 